\title{
Effect of Hydrogen Peroxide on Cyclic Fatigue Resistance of NiTi Endodontic Files
}

\author{
Huma Sarwar ${ }^{1}$ \\ Meshal M Naeem ${ }^{2}$ \\ Sumaiya Shabbir ${ }^{3}$ \\ Sania Riaz ${ }^{4}$ \\ Hasan Afaq ${ }^{5}$ \\ Juzer Shabbir ${ }^{6}$
}

\author{
BDS, MDS \\ BDS \\ BDS, MSc \\ BDS, MSc \\ BDS, MDS \\ BDS, MDS
}

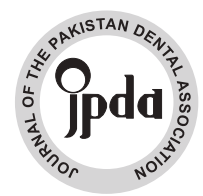

OBJECTIVE: To investigate the effect of nickel titanium rotary endodontic file immersion in hydrogen peroxide on cyclic fatigue resistance.

METHODOLOGY: Twenty Six Protaper Universal (Dentsply Maillerfier) F1 files were randomly divided into two experimental groups. In Group I, Protaper universal variable taper F1 files were immersed in normal saline where as in Group II, the files were soaked in hydrogen peroxide $(6 \% \mathrm{w} / \mathrm{v})$ for 2 hours at $37^{\circ} \mathrm{C}$. Cyclic fatigue of each file was checked by recording the number of rotations required to break a file in a $90^{\circ}$ curve with a $5 \mathrm{~mm}$ radius. For statistical analysis of data, Two-way ANOVA was applied. A p value of $<0.05$ was considered significant.

RESULT: Out of Twenty Six, Six files fractured spontaneously after immersion in hydrogen peroxide. Twenty files were subjected to fracture resistance testing. Statistically significant difference in cyclic fatigue resistace between the two groups was found ( $\mathrm{p}=0.002$ ). The files soaked in Group II required less revolutions to fracture than the ones immersed Group I. CONCLUSION: The immersion of NiTi endodontic files in hydrogen peroxide significantly reduces cyclic fatigue resistance. Therefore, immersion of the NiTi endodontic files in hydrogen peroxide solution for removal of clogged debris should be discouraged.

KEYWORDS: Cyclic fatigue, Endodontic instruments, Hydrogen peroxide, NiTi

HOW TO CITE: Sarwar H, Naeem MM, Shabbir S, Riaz S, Afaq H, Shabbir J. Effect of hydrogenperoxide on cyclic fatigue resistance of NiTi endodontic files. J Pak Dent Assoc 2020;29(4):246-248.

DOI: https://doi.org/10.25301/JPDA.294.246

Received: 10 March 2020, Accepted: 15 August 2020

\section{INTRODUCTION}

1 ndodontic therapy is aimed to shape and clean roots canals to an adequate geometry. The main objective of the mechanical preparation is to optimize the disinfection and subsequent obturation of the whole root canal system. ${ }^{1}$ Endodontic files are used to shape root canal mechanically. Hydrogen peroxide has been used as an endodontic irrigant in varying concentrations. Although the

1. Lecturer, Department of Operative Dentistry, Dow University of Health Sciences

2. Lecturer, Department of Periodontology, Dow University of Health Sciences, Karachi

3. Lecturer, Department of Periodontology, Dow University of Health Sciences, Karachi

4. Lecturer, Department of Periodontology, Dow University of Health Sciences, Karachi

5. Senior Lecturer, Department of Operative Dentistry, Baqai Dental College, Baqai Medical University.

6. Senior Lecturer, Department of Operative Dentistry, Liaquat College of Medicine and Dentistry, Karachi.

Corresponding author: “Dr. Huma Sarwar” < humashal@ hotmail.com > current evidence does not support the use of hydrogen peroxide over other contemporary irrigants, it is still used by dental practitioners to remove dentine debris from endodontic files. According to the Archimedes screw effect, the flutes of the files tend to transport clogged dentinal debris coronally during endodontic preparation. ${ }^{2}$ The clogged debris compromises the cleaning efficiency of the endodontic instrument. Hence, the cleaning of the endodontic instrument is mandatory before it can be used again. To date, there is no standardized method for cleaning endodontic files after usage. The files can either be cleaned by wiping with gauze or sponge soaked with alcohol or by using an ultrasonic bath. ${ }^{3}$ In our part of the world, most of the dental practitioners prefer to soak freshly used endodontic files in agents such as sodium hypochlorite or hydrogen peroxide for this purpose. ${ }^{4}$ There is a high risk of endodontic NiTi rotary instruments fracture because of torsional shear stresses and 
cyclic fatigue. ${ }^{5}$ The mechanical properties of rotary instruments are also compromised by when the files remain in contact with chemicals for the longer time duration. Sodium hypochlorite has proven to decrease the cyclic fatigue resistance of rotary files. ${ }^{6}$ Rotations around a curve causing repeated compression and extension of a metal results in work hardening and eventually separation of the instrument. This phenomenon is known as cyclic fatigue of an instrument. Now days efforts are being made to identify the factors and that effect the cyclic fatigue of the endodontic instruments. Nickel Titanium (NiTi) surfaces are being modified by electro-polishing and ion deposition to enhance mechanical properties. ${ }^{7}$ Corrosion in the presence of solution used during root canal treatment is another important factor affecting the mechanical strength of NiTi files. ${ }^{8}$ Because of its tissue dissolving and hemostatic properties, hydrogen peroxide was used as an intracanal irrigant. Sodium hypochlorite is gold standard endodontic irrigant known for its tissue dissolving properties. According to the literature, sodium hypochlorite tends to corrode NiTi and stainless steel files structure. ${ }^{9}$ But the effect of hydrogen peroxide on mechanical properties of Niti endodontic files is not known. Therefore, the objective of the present study was to evaluate the effect of hydrogen peroxide on the cyclic fatigue resistance of NiTi endodontic files.

\section{METHODOLGY}

Twenty-six Protaper universal (Dentsply Maillerfier) F1 variable taper files were used in this study. Files were divided randomly int two groups. In Group I (Control group), the files were soaked in normal saline. In Group II (experimental Group), the files were soaked in hydrogen peroxide. The files were stored at room temperature for 2 hours in glass vials according to the assigned group and after removal were wiped with gauze. Files were then tested for cyclic fatigue after air drying by using universal testing machine. A tempered steel rod and a block assembled with a $5 \mathrm{~mm}$ radius and $90^{\circ}$ angle were used to evaluate fracture resistance by measuring the number of rotations to fracture. Files were immersed in neighbourhoods in a way that their tips were extending out of the rod. $240 \mathrm{rpm}$ rotational speed was set. The number of rotations required to fracture the files was calculated. The lubricant was used to reduce heat generation. Scheffe post hoc test and Two-way analysis were used at $=0.05$ for the evaluation of the data. The number of rotations, angle and torque were dependent variables.

\section{RESULTS}

Three files from both groups i.e six out of twenty six endodontic files showed obvious signs of corrosion and resulted in breakage. Twenty files were subjected to evaluation of fatigue resistance testing. According to the results, the maximum and minimum number of rotations required to

Table 1: Comparison of mean revolutions to facture for hydrogen peroxide and normal saline groups

\begin{tabular}{|l|c|c|c|}
\hline & Mean(Revolutions to fracture ") & SD & P value \\
\hline $\begin{array}{l}\text { GROUP I (Normal } \\
\text { Saline) }\end{array}$ & 209 & 20 & $0.002^{*}$ \\
\hline $\begin{array}{l}\text { GROUP II (Hydrogen } \\
\text { peroxide) }\end{array}$ & 125 & 45 & \\
\hline
\end{tabular}

$90^{\circ}$ curve; $5 \mathrm{~mm}$ radius of curvature* $\mathrm{p}$-values $<0.05$ considered as significant (ANOVA)

fracture the files was 80 and 229. Statistically significant difference in number of revolutions required to fracture the files was found between Group I and Group II ( $p<0.05)$. The files in Group I showed significantly higher resistance to cyclic fracture as compared to Group II (Table 1).

\section{DISCUSSION}

Hydrogen peroxide has been used as an intracanal irrigant for many years. Its use as an intracanal irrigation solution is no more recommended. Still, many general dental practitioners use hydrogen peroxide as an irrigant and also the removal of clogged debris removal from endodontic files after use. The present study evaluated the effect of immersion of rotary Protaper F1 file in hydrogen peroxide solution $(6 \% \mathrm{w} / \mathrm{v})$ marked reduction in fatigue resistance was noted. The tested platform used in this study has been extensively used in the past for evaluation of fatigue resistance. It is worth noting that before immersion of files in hydrogen peroxide, Protaper Universal F1 files were more resistant to fatigue. For the testing of fatigue resistance, the design described in another study ${ }^{10}$ was used. As the heat negatively affects the fatigue resistance, measures were taken to avoid overheating of the rod and block assembly. ${ }^{11}$ Conditions tested were similar in other studies ${ }^{12,13}$ in comparison to present experiment. It has been suggested that more rapid and frequent corrosion occurs when the working part and the shank of the instrument is immersed into the solution which enables galvanic corrosion..$^{12,13}$

Many studies reported the effect of sodium hypochlorite solution on the physical properties of endodontic files. The results showed significant reduction in torsional and fatigue resistance when files were soaked in sodium hypochlorite resulting in corrosion. ${ }^{6,9}$

There is no consensus yet if corrosion presents a clinical problem. Though it may be challenging to remove adhering material from the used endodontic file without its complete 
Sarwar H/ Naeem MM/ Shabbir S/ Riaz S/ Afaq H/ Shabbir J

immersion in solution, it is still not known if the cleaning protocol of the endodontic rotary files is capable of eliminating the adhere dentinal debris completely. ${ }^{14,15}$

Gross signs of corrosion were present in 6 of $25 \mathrm{NiTi}$ endodontic files placed in hydrogen peroxide solution. This observation is most likely because of the galvanic corrosion. In a few files, galvanic corrosion leads to swift total destruction and only mild pitting and surface changes in other endodontic files. Potential mechanism of galvanic cell development is a breach of nickel or gold plating in the handle part. Galvanic corrosion results in nobular areas that give an image of sponge-like structure. ${ }^{16}$ Manufacturing marks are the minor defects that may initiate subsequent file separation. It can be postulated from this study that localized and small areas of pitting corrosion reduces the cyclic fatigue of NiTi endodontic instruments.

\section{CONCLUSION}

This is apparent from this study that a high risk of corrosion is associated with soaking endodontic files in hydrogen peroxide solution. Therefore, immersion of files in hydrogen peroxide for removal of attached debris is not recommended.

\section{CONFLICT OF INTEREST}

None

\section{FINANCIAL DISCLOSURE}

None

\section{REFERENCES}

1. Tziafas D, Alraeesi D, Al Hormoodi R, Ataya M, Fezai H, Aga N. Preparation prerequisites for effective irrigation of apical root canal: a critical review. J Clin Exp Dent . 2017;9(10):e1256.

https://doi.org/10.4317/jced.54117

2. Carrotte PV. Current practice in endodontics: 4. A review of techniques for canal preparation. Dent Update. 2000;27:488-93. https://doi.org/10.12968/denu.2000.27.10.488

3. Murgel CAF, Walton RE, Rittman B, Pécora JD. A comparison of techniques for cleaning endodontic files after usage: a quantitative scanning electron microscopic study.J Endod 1990;16:214-7. https://doi.org/10.1016/S0099-2399(06)81672-9

4. Sarwar, Huma et al. "Knowledge and Attitute of Dental Practitioners of Karachi towards Usage of Endodontic Files: A Cross Sectional Study.Saudi J Oral Dent Res 2019;4:747-50 https://doi.org/10.36348/SJODR.2019.v04i10.010
Effect of hydrogen peroxide on cyclic fatigue resistance of NiTi endodontic files.

5. Yao JH, Schwartz SA, Beeson TJ. Cyclic fatigue of three types of rotary nickel-titanium files in a dynamic model. J Endod 2006;32:557.

https://doi.org/10.1016/j.joen.2005.10.013

6. Elnaghy A, Elsaka S. Effect of sodium hypochlorite and saline on cyclic fatigue resistance of WaveOne Gold and Reciproc reciprocating instruments. Int Endod J 2017;50:991-98.

https://doi.org/10.1111/iej.12712

7. Anderson ME, Price JW, Parashos P. Fracture resistance of electropolished rotary nickel-titanium endodontic instruments. J Endod 2007;33:1212-16.

https://doi.org/10.1016/j.joen.2007.07.007

8. O'hoy P, Messer H, Palamara J. The effect of cleaning procedures on fracture properties and corrosion of NiTi files. Int Endod J 2003;36:724-32.

https://doi.org/10.1046/j.1365-2591.2003.00709.x

9. Peters OA, Roehlike JO, Baumann MA. Effect of immersion in sodium hypochlorite on torque and fatigue resistance of nickel-titanium instruments. J Endod 2007;33:589-93.

https://doi.org/10.1016/j.joen.2007.01.007

10. Haikel Y, Serfaty R, Bateman G, et al. Dynamic and cyclic fatigue of engine-driven rotary nickel-titanium endodontic instruments. J Endod 1999;25:434-40

https://doi.org/10.1016/S0099-2399(99)80274-X

11. Kuhn G, Jordan L. Fatigue and mechanical properties of nickeltitanium endodontic instruments. J Endod 2002;28:716-20 https://doi.org/10.1097/00004770-200210000-00009

12. Berutti E, Angelini E, Rigolone M, et al. Influence of sodium hypochlorite on fracture properties and corrosion of ProTaper rotary instruments. Int Endod J 2006;39:693-9.

https://doi.org/10.1111/j.1365-2591.2006.01134.x

13. Castro Martins R, Bahia MGA, Buono VTL. The effect of sodium hypochlorite on the surface characteristics and fatigue resistance of ProFile nickel-titanium instruments. Oral Surg Oral Med Oral Path Oral Radiol Endod 2006;102:99-105.

https://doi.org/10.1016/j.tripleo.2006.02.018

14. Sonntag D, Peters OA. Effect of prion decontamination protocols on Nickel-Titanium rotary surfaces. J Endod 2007;

https://doi.org/10.1016/j.joen.2006.12.012

15. Linsuwanont $P$, Parashos $P$, Messer HH. Cleaning of rotary nickeltitanium endodontic instruments. Int Endod J 2004;37:19-28 https://doi.org/10.1111/j.1365-2591.2004.00747.x

16. Sonntag D, Heithecker K. Korrosion von Nickel-Titan-Instrumenten. Endodontie 2006;15:23-30. 